\title{
The Attitudes and Awareness of Urinary Bladder Cancer Patients about the Relationship Between Their Tumoral Diseases and Tobacco Exposure
}

\section{Ürotelyal Kanserli Hastalarda Hastalıklarının Tütün Dumanına Maruziyeti İle İlişkisi Konusunda Tutum ve Farkındalıklarının Değerlendirilmesi}

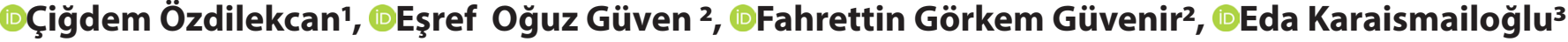 \\ 'University of Health Sciences Dr. Abdurrahman Yurtaslan Oncology Research and Training Hospital, Department of Pulmonology, Ankara, Turkey \\ ${ }^{2}$ University of Health Sciences Dr. Abdurrahman Yurtaslan Oncology Research and Training Hospital, Department of Urology, Ankara, Turkey \\ ${ }^{3}$ Kastamonu University School of Medicine , Department of Biostatistics, Kastamonu, Turkey
}

\begin{abstract}
Aim: To investigate the urinary bladder cancer (UBC) patients about their smoking behaviors and to find out the answer for their attitudes and awareness of the exposure cancer relationship.

Material and Method: A cross- sectional study was conducted between January 2018-December 2019.

Results: One hundred seventy- nine histopathologically proven UBC patients were included. The majority of patients $(57.1 \%)$ attempt to quit smoking before diagnosis. $42.9 \%$ of them quitted during diagnostic procedures or after being diagnosed as cancer. No significant relationship was found between the smoking status and recurrence of the primary tumoral disease. The grade of the primary tumor and chemotherapy applications did not affect the smoking status of the patients $(p=0.521$ and $p=0.949$ respectively). When the awareness about their smoking behavior which was one of the major causes for their bladder cancer was asked; $60 \%$ of the participants were absolutely not aware. When the main reason for smoking cessation was asked, the positive influence and strong advice of healthcare professionals for quit smoking were the most important factor for the patients. However, either gradually worsening quality of life or suffering from serious respiratory illnesses (COPD, asthma ) were not the major factors to quit smoking.

Conclusions: Majority of the patients didn't have any or particularly had idea about the relationship between smoking and urothelial cancers. Among the patients who had harm perception of smoking on their tumoral diseases, majority didn't believe that quitting would be beneficial after being diagnosed as cancer.
\end{abstract}

Keywords: Awareness, knowledge, urinary bladder cancer, tobacco smoking
Öz

Amaç: Ürotelyal kanser hastalarında tütün maruziyet durumunun, primer hastalıkları ile bu maruziyet ilişkisi konusunda bilgi ve farkındalıklarının değerlendirilmesi amaçlandı .

Gereç ve Yöntem: Ocak 2018-Aralık 2019 tarihleri arasında kesitsel çalışma olarak yapıldı.

Bulgular: Çalışmaya histopatiolojik olarak kesin tanı almış 179 hasta dahil edildi. Hastaların çoğunluğu $(\% 57,1)$ tanıdan önce sigarayı bırakma girişiminde bulunmuşlardı. \%42,9'u ise tanısal işlemler sırasında veya kanser tanısı aldıktan sonra sigarayı bırakmışlardı. Sigara içme durumları ve hastalık rekürrensleri arasında belirgin bir ilişki bulunmadı.Primer tümörün diferensiyasyon derecesi ve kemoterapi uygulamaları hastaların sigara içme durumlarını etkilememişti (sırasıyla $p=0,521$ and $p=0,949$ ). Mesane kanseri etyolojisinin major etkenlerinden biri olarak sigara içimi konusundaki farkındalıkları sorgulandığında katılımcıların \%60'ı mutlak olarak farkında değildi. Sigarayı bırakmadaki ana nedenleri sağlık çalışanlarının pozitif etkileri ve kuvvetli önerileri en önemli faktördü. Ancak ne giderek bozulan yaşam kaliteleri ne de ciddi solunumsal hastalık varlığı ( $\mathrm{KOAH}$, astım ) varlığı major bir sigara bırakma nedeni olamamıştı.

Sonuç: Hastaların çoğunluğu sigara ve ürotelyal tümör ilişkisinden hiçbir şekilde bilgiye sahip değildi veya kısmen bilgi sahibiydi..Tümoral hastalıklarında sigaranın etkisi olduğu konusunda zarar algısı olan hastaların çoğunluğu ise kanser tanısı aldıktan sonra bırakmanın bir faydası olmayacağına inanıyordu.

Anahtar Kelimeler: Farkındalık, bilgi, mesane kanseri, tütün içimi

Corresponding (illetişim): Çiğdem Özdilekcan, Dr.Abdurrahman Yurtaslan Ankara Onkoloji Hastanesi, 06200 Demetevler, Yenimahalle, Türkiye E-mail (E-posta): cigdemozdilekcan@yahoo.com.tr

Received (Gelis Tarihi): 25.06.2020 Accepted (Kabul Tarihi): 08.08.2020 


\section{INTRODUCTION}

Urothelium is the specialised epithelium covering the urinary system. The main etiological factors for urinary bladder cancers are cigarette smoking and occupational exposure. ${ }^{[1]}$ However, drugs like phenacetin, chlornaphazine, and cyclophosphamide ,infections like Schistosoma haematobium, genotypes such as NAT2 slow acetylator and GSTM1 null are also associated with an increased risk of this cancer. Such genotypes are associated with increased risk of UBC presumably because of their reduced ability to detoxify carcinogens. ${ }^{[2]}$ Cigarette smoking has been historically established as risk factor for urothelial cancer, and an association with risk of renal cell carcinoma and worse prognosis of prostate cancer has been demonstrated..$^{[3]}$ Cigarette smoking increases the risk of UBC up to 2 to 10 fold. ${ }^{[4]}$ Previous studies indicated a reduction in risk by more than $30 \%$ within the first year to 4 years after cessation of smoking, and more than $60 \% 25$ years after cessation, but even after 25 years the risk still does not reach the background level of never smokers..$^{[5]}$ Smoking cessation may decrease recurrence rates for patients with nonmuscle-invasive disease. ${ }^{[6]}$ When focused on the never smoker population with cancer, exposure to secondhand smoke in women may be a risk factor for the development of bladder cancer. ${ }^{[7]}$

Although there is a great concern among physicians that the relationship between smoking and UBC is nearly clear but somehow the information, knowledge and awareness of people suffering from this illness is an issue that should be investigated. Since tobacco exposure is commonly known to affect respiratory system, several other indirect effects of smoking might be underestimated by the patients. The first rule for the patients to quit and prevent smoking is to hear the "strong recommendation from healthcare professionals".

Only limited studies have shown the communication between patients and their physicians regarding their disease and smoking as well as the awareness and knowledge of UBC patients about the influence of smoking regarding their primary cancer diseases. ${ }^{[8]}$

In this study we aimed to investigate the UBC patients with their history of smoking (tobacco exposure) and to find out the answer for their attitudes and awareness of the exposure - cancer relationship. Moreover, we aimed to show the association between smoking status with the stage, grade and histopathology of the tumoral disease.

\section{MATERIAL AND METHODS}

\section{Study conduction}

Demographic, oncological, surgical and clinical informations with a questionnaire about knowledge and awareness was obtained from all contributors. Totally 21 items were prepared and recorded for assessment of the aforementioned situations. These included age, gender, body mass index(BMI),occupation, educational level, histopathological diagnosis, tumor stage, time of the diagnosis, type of the surgical procedure, history of chemotherapy history of BCG (Bacillus Calmette-Guérin) vaccination and presence of recurrence for the primary disease, history of lung diseases (asthma and chronic obstructive pulmonary disease (COPD), pneumonia, pleurisy), alcohol consumption, smoking and quitting status.

Tumor staging was assessed according to European Association of Urology Guidelines on Non-muscle-invasive Bladder Cancer (TaT1 and Carcinoma In Situ) - 2019 Update. ${ }^{[9]}$ Treatment approach was categorized according to European Association of Urology (EAU) Oncology Guidelines. ${ }^{[10]}$

Smoking behavior was defined as never smokers, current smokers (package/year given in numbers), former smokers and second- hand (passive) smokers. Former smokers were asked for their quitting time either before/after diagnosis. Current smokers were also asked for their attending quitting in any time course of their lives.

\section{Questions about awareness and attitudes}

The patients were asked to give the answer of the following questions within the following choices:

1. "Are you aware of the fact that one of the major cause of your illness is your smoking habit?"The question was a 'yes' or 'no' question.

2. "What was your main reason or factor for quitting smoking?" the choice of answers were as follows: a)The positive influence and advise of health care specialist (physicians and nurses). b) having knowledge of the negative effect of smoking on his/her primary disease, c) having knowledge of the negative effect of smoking on treatment response by causing co-morbidities. d) being unable to smoke because of the worsening of quality of life. e) Suffering from a life-threatening pulmonary disease (COPD exacerbations or pneumonia).

3. If they have not quitted; explanation for this situation was asked. "Why didn't you quit smoking?"

a) I have no idea about the negative effects of smoking on my primary disease and my personal health.

b) I have an idea about the negative effects of smoking on my primary disease and my personal health however, I am not willing to stop since I don't believe that quitting will be beneficial from now on.

\section{Study Population}

The design of the study was cross-sectional conducted in a single center. The data of patients between 2018 May2019 February followed -up in Oncology Hospital have been collected.179 volunteer patients with accurate diagnosis of urothelial bladder carcinoma were included in the study. The data were obtained from adult volunteer bladder cancer patients with $>18$ years of age who contributed to the questionnaires.

\section{Exclusion criteria}

Individuals who suffer from mental or neurological diseases leading to lack of cooperation for the questionnaires and unable to give reliable answers were excluded.

\section{Ethical consideration}

The Ethics Committee of Ankara Oncology Hospital,Turkey approved the protocol, dated September 2018 Number: 201809/138. All subjects provided written informed consent. Data 
of the patients were treated according to the Declaration of Helsinki Guidelines.

\section{Statistical analysis}

Descriptive statistics were performed for all data. For continuous variables, results were presented as mean \pm standard deviation. Categorical variables were presented by frequency and percentage. Comparisons between two categorical variables were performed using the chi-square analysis. All analyses were performed using IBM SPSS Statistics 21 (IBM, Armonk, NY USA). All tests were two-sided and a P value of less than 0.05 was considered to be statistically significant.

\section{RESULTS}

Of the 179 UBC patients 154 were male and 25 were female (86\%,14\% respectively). In Table 1 demographic data and clinical presentation of study group are shown. The mean age was $64.02 \pm 11.58$. Patients had mean body mass index $(\mathrm{BMI}): 25.26 \pm 3.35(<30)$ indicating the group with nonobese feature. The duration of diagnosis $35.25 \pm 22.47$ months. Smoking history of patients revealed 47 never smokers, 74 former smokers,58 current smokers $(26.3 \%, 41.3 \%, 32.4 \%$ respectively). The mean package of cigarette consumption among the study population was $27.62 \pm 9.4$. Attempt to quit was asked for all patients regarding the diagnostic period. As shown in Table, the majority of patients $(57.1 \%)$ tried to quit before diagnosis. $42.9 \%$ of them quitted during diagnostic procedures or after being diagnosed as cancer.

\begin{tabular}{|c|c|c|c|}
\hline \multicolumn{2}{|l|}{ Variables } & \multirow{2}{*}{$\begin{array}{c}\text { Frequency (\%) } \\
154(86)\end{array}$} & \multirow[t]{2}{*}{ Mean \pm SD } \\
\hline \multirow{2}{*}{ Gender } & Male & & \\
\hline & Female & $25(14)$ & \\
\hline \multicolumn{2}{|l|}{ Age } & & $64.02 \pm 11.58$ \\
\hline \multicolumn{2}{|l|}{ Body Mass Index } & & $25.25 \pm 3.35$ \\
\hline \multicolumn{2}{|c|}{ Time of diagnosis (months) } & & $25.25 \pm 22.47$ \\
\hline \multirow{2}{*}{$\begin{array}{l}\text { Educational } \\
\text { Status }\end{array}$} & Primary School Education & $137(76.5)$ & \\
\hline & Higher Education & $42(23.5)$ & \\
\hline \multirow{2}{*}{ Chemotherapy } & Non & $176(98.3)$ & \\
\hline & Applied & $3(1.7)$ & \\
\hline \multirow{2}{*}{$\begin{array}{l}\text { BCG } \\
\text { Vaccinations }\end{array}$} & Non & $144(80.4)$ & \\
\hline & Applied & 35 (19.6) & \\
\hline \multirow{2}{*}{$\begin{array}{l}\text { Disease } \\
\text { Recurrence }\end{array}$} & None & $134(74.9)$ & \\
\hline & Occurred & $45(25.1)$ & \\
\hline \multirow{3}{*}{$\begin{array}{l}\text { Previous } \\
\text { Respiratory } \\
\text { Disease }\end{array}$} & COPD & $17(9.5)$ & \\
\hline & Asthma & $10(5.6)$ & \\
\hline & Pneumonia & $7(3.9)$ & \\
\hline \multirow{2}{*}{$\begin{array}{l}\text { Alcohol } \\
\text { consumption }\end{array}$} & None & $142(79.3)$ & \\
\hline & Consumed & $37(20.7)$ & \\
\hline \multirow{4}{*}{ Tumor Grade } & T0G3 & $20(11.2)$ & \\
\hline & CIS & $6(3.4)$ & \\
\hline & $\mathrm{T} 1 \mathrm{G} 3$ & $40(22.3)$ & \\
\hline & TaG1 & $113(63.1)$ & \\
\hline \multirow{3}{*}{ Smoking Status } & Never smoker & $47(26.3)$ & \\
\hline & Former smoker & $74(41.3)$ & \\
\hline & Current smoker & $58(32.4)$ & \\
\hline
\end{tabular}

Table 2 showed the characteristics of patients and relationship with smoking status. Smoking status was defined as never smoker, former smoker and current smoker. There was a statistically significant difference between the smoking status and male gender $(p=0.001)$. Educational status of patients did not affect smoking status ( $p>0.005$ ), The grade of the primary tumor and chemotherapy applications also did not affect the smoking status of the patients $(p=0.521$ and $p=0.949$ respectively).No significant difference was found between the remaining parameters and smoking status, including recurrence of the primary tumoral disease.

Table 2. Characteristics of patients and relationship with smoking status

\begin{tabular}{|c|c|c|c|c|c|}
\hline \multirow{2}{*}{ Variables } & & \multicolumn{3}{|c|}{ Smoking Status } & \multirow[b]{2}{*}{$P$ value } \\
\hline & & Never & $\begin{array}{l}\text { Former } \\
\text { smoker }\end{array}$ & $\begin{array}{l}\text { Current } \\
\text { smoker }\end{array}$ & \\
\hline \multirow{2}{*}{ Gender } & Male & $24(15.6)$ & $72(46.8)$ & $58(37.7)$ & \multirow{2}{*}{$<0.001$} \\
\hline & Female & $23(92.0)$ & $2(8.0)$ & $0(0)$ & \\
\hline \multirow{2}{*}{$\begin{array}{l}\text { Educational } \\
\text { Status }\end{array}$} & $\begin{array}{l}\text { Primary } \\
\text { Education }\end{array}$ & 39 (28.5) & 57 (41.6) & $41(29.9)$ & \multirow{2}{*}{0.329} \\
\hline & $\begin{array}{l}\text { Higher } \\
\text { Education }\end{array}$ & $8(19.0)$ & $17(40.5)$ & $17(40.5)$ & \\
\hline \multirow{4}{*}{ Tumor Grade } & T0G3 & $5(25.0)$ & $8(40.0)$ & $7(35.0)$ & \multirow{4}{*}{0.521} \\
\hline & $\mathrm{CIS}$ & $3(50.0)$ & $3(50.0)$ & $0(0)$ & \\
\hline & T1G3 & $10(25.0)$ & $17(42.5)$ & $13(32.5)$ & \\
\hline & TaG1 & $29(25.7)$ & $46(40.7)$ & 38 (33.6) & \\
\hline \multirow{2}{*}{$\begin{array}{l}\text { BCG } \\
\text { Vaccinations }\end{array}$} & Non & $39(27.1)$ & $59(41.0)$ & 46 (31.9) & \multirow{2}{*}{0.874} \\
\hline & Applied & $8(22.9)$ & $15(42.9)$ & $12(34.3)$ & \\
\hline \multirow{2}{*}{ Chemotherapy } & Non & $46(26.1)$ & $73(41.5)$ & $57(32.4)$ & \multirow{2}{*}{0.949} \\
\hline & Applied & $1(33.3)$ & $1(33.3)$ & $1(33.3)$ & \\
\hline \multirow{2}{*}{$\begin{array}{l}\text { Disease } \\
\text { Recurrence }\end{array}$} & None & $39(29.1)$ & $53(39.6)$ & $42(31.3)$ & \multirow{2}{*}{0.305} \\
\hline & Occurred & $8(17.8)$ & $21(46.7)$ & 16 (35.6) & \\
\hline
\end{tabular}

In the questionnaire, some additional questions were asked to UBC patients in order to observe their awareness, behavior and knowledge about their primary disease and relationship between the smoking habit. The first question was 'Are you aware of the fact that one of major the cause of your illness is your smoking habit?' the answer given by the patients was $60 \%$ no, $\% 30$ was yes and $10 \%$ was no or had no idea. This exactly means that majority of patients did not have any idea about the relationship between smoking and bladder cancer. Second question was "Which factor or factors played role for your decision to quit during your treatment course ? "What was your main reason or factor for quitting smoking? and the answer choices were shown in Figure 1. Apparently, the positive influence and strong advice of healthcare professionals for quit smoking were the most important factors for the UCB patients, however, either gradually worsening quality of life or suffering from serious respiratory illnesses were not the major factors to quit smoking. Ultimately, If they have not quitted smoking during treatment period; the explanation for this situation was asked. "Why didn't you quit smoking ?" 


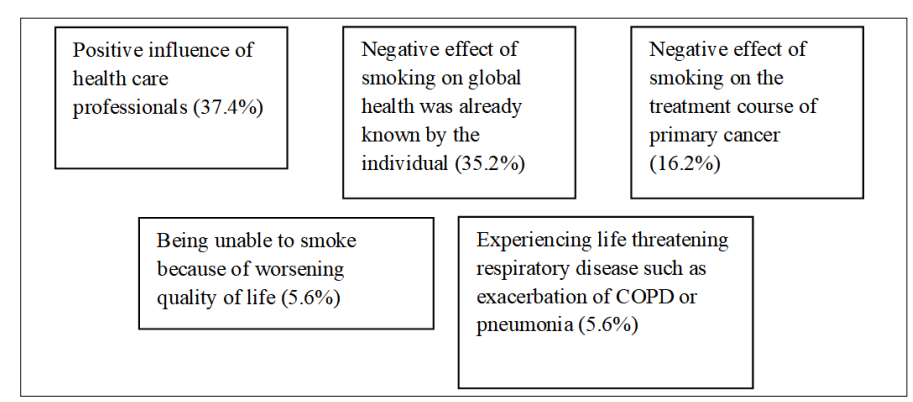

Figure 1. Different factors those played role for decision to quit during treatment of primary disease.

a)I had no idea about the negative effects of smoking on my primary disease course (27\%).

b) I had an idea about the negative effects of smoking on my primary disease and my personal health however, I did not believe that quitting will be beneficial from now on after cancer diagnosis (83\%).

Among the patients who had awareness about the causative effects of smoking on their tumoral diseases, majority of them unfortunately did not believe that quitting would be beneficial after being diagnosed as cancer. The patients were disappointed and lost their belief about the relationship between being overall healthy and smoking cessation.

\section{DISCUSSION}

The main outcome of our study was the lack of patients' awareness about their smoking habit which was one of the major cause for their urinary cancers .Secondly, the main reason for smoking cessation was the positive influence and strong advice of healthcare professionals for quit smoking; however, dramatically either gradually worsening quality of life or suffering from serious respiratory illnesses were not the major factors to quit smoking. Thirdly, the patients who had awareness about the causative effects of smoking on their tumoral diseases majority of them unfortunately didn't believe that quitting would be beneficial after being diagnosed as cancer. The grade of the primary tumor and chemotherapy applications did not affect the smoking status of the patients. The patients were disappointed and lost their belief about the relationship between being overall healthy and smoking cessation.

According to the estimations of World Health Organization in 2013, six million people worldwide died from the diseases caused by smoking including cancer, cardiovascular diseases and pulmonary diseases. ${ }^{[8]}$ Cigarette smoking and occupational exposure are the main risk factors for urothelial carcinoma. In urinary bladder cancer (UBC), cigarette smoking is responsible for about one-third of all diagnosis. Tobacco exposure is not only an etiological factor for urothelial carcinoma, but also a risk factor for the disease recurrence as stated in the previous literature. ${ }^{[11,12]}$ In our study the grade of the primary tumor and chemotherapy applications did not affect the smoking status of the patients. No significant difference was found between the remaining parameters and smoking status, including recurrence of the primary tumoral disease. In a previous study of Sfakianos JP et al. ${ }^{[13]}$ smoking did not appear to affect the response to BCG therapy and long-term oncological results. Ide $\mathrm{H}$ et al. ${ }^{[14]}$ emphasized that urinary $\mathrm{pH}$ levels were strongly associated with recurrence in patients with smoking history in their study published in 2016. They also recommended urine alkalization for avoiding bladder recurrence.

Although there is a great concern among physicians that the relationship between smoking and UBC is nearly clear but somehow the information, knowledge and awareness of people suffering from this illness is an issue that should be investigated. The first rule for the patients to quit and prevent smoking is to hear the "strong recommendation from healthcare professionals". Our study results also revealed that, the positive influence of healthcare professionals for quit smoking were the most important factor for the UCB patients, however either the worsening of quality of life or suffering from serious respiratory illnesses were not the major powerful factors to quit smoking. This was an interesting outcome indicating that strong recommendation and honest relationships with the health care providers are more important than suffering from serious pulmonary symptoms or diseases. Majority of patients were disappointed and lost their belief about the relationship between being overall healthy and smoking cessation. Therefore, continuous encouragement is essential by the urologists and by the other health care providers who contribute to the follow-up of patients. The term "teachable moment" was used by Lee et al..$^{[15]}$ which defined the lifestyle modification of patients at the time of cancer diagnosis including smoking cessation or even reduction. For this aim, urologists should also be aware of their function as primary contact for patients and ensure compliance and lifestyle changes during their treatment and follow-up courses.

In the previous study of May M et al. ${ }^{[16]}$ about prostate cancer which has a dose-dependent relationship with smoking; education of prostate cancer patients about the relationship between cigarette consumption and cancer-related prognosis was inadequate. They also made additional comment that, urologists should have pursued informational discussions with their patients, thereby strengthening their position as the primary contact person for decision making in prostate cancer management. Our study results indicated that there is a little concern about smoking and urothelial cancer among the patients and majority of patients did not have any idea about the relationship between smoking and urothelial cancers. Additionally, mostly believed issue was the smoking relationship with the overall health, but not targeted at especially urothelial cancers. We think that lack of awareness was associated with the location of the tumor which might not be affected by an inhalation hazardous material. Since tobacco exposure is commonly known to affect respiratory system several other indirect effects of smoking might be underestimated by the patients. 
Tobacco use is known as one of the most important causes of preventable diseases worldwide those cause morbidity and mortality Physicians are responsible for their patients' overall health status both by being a role model with their smoking related behaviors. Tobacco dependence treatment includes brief advice and counseling for smoking prevention and cessation and recommending or prescribing cessation medications when needed. ${ }^{[17]}$ Similar to our study design, Gray et al. ${ }^{[18]}$ investigated the patients with oral and oropharyngeal cancer and reported the impact of their diagnosis on smoking cessation. Even after diagnosis of cancer high number of their current smoker patients continued to smoke. Therefore, they concluded that smoking cessation would reduce the risk of recurrence and improve treatment outcomes with proactive approaches by the healthcare professionals. Similar to our results a recent study published in 2016 demonstrated that most UBC survivors did not suspect any cause that might have contributed to the development of their cancer. Therefore, effective education was emphasized for the superficial knowledge of risk factors for bladder cancer. ${ }^{[19]}$

\section{The strength and limitation of the study}

Our study directly interrogated patients about their behaviors and attitudes through smoking habits and disease course in a single center. It demonstrated the incidence of smoking among urothelial cancer patients in an oncology hospital located in Turkey. As well the incidence, the outcome of this study revealed that more supportive approaches and encouragement are needed by health care providers. Since the self - reports were taken into consideration, there was no biochemical validation of smoking cessation. We think that self-reporting in some degree led to some underestimation of smoking prevalence. Overall data for face to face questionnaires were based upon the statements of patients which could be possibly assumed as subjective results, hence further studies can be conducted concerning the objective -confirming measurable data about indicators of smoking.

\section{CONCLUSIONS}

According to our study results, no satisfactory result was obtained for the awareness of patients in such a cancer whose etiology was closely related with tobacco exposure. This result also indicated that education of urothelial tumor patients about tobacco exposure was inadequate. In order to maintain the awareness of the patients, further educational attempts about this exposure by the health care professionals are needed based upon the etiology of their diseases, negative impact on their treatment courses as well as triggering respiratory co-morbidities. Having knowledge and information is an important power to give a start about the behavioral changes about smoking. The patients were disappointed and lost their belief about the relationship between being overall healthy and smoking cessation. Therefore, the impact of convincing and honest motivational relationship between patients and physicians is the most important factor for knowledge and attitudes of patients both for current and future approaches.

\section{ETHICAL DECLARATIONS}

Ethics Committee Approval: The Ethics Committee of Ankara Oncology Hospital, Turkey approved the protocol, dated September 2018 Number: 2018-09/138.

Informed Consent: All patients signed the free and informed consent form.

Referee Evaluation Process: Externally peer-reviewed.

Conflict of Interest Statement: The authors have no conflicts of interest to declare.

Financial Disclosure: The authors declared that this study has received no financial support.

Author Contributions: All of the authors declare that they have all participated in the design, execution, and analysis of the paper, and that they have approved the final version.

Acknowledgement: The authors would like to thank Mrs. Esra Ay from Oncology Hospital for her excellent support during the data collection.

\section{REFERENCES}

1. Miyazaki J, Nishiyama H. Epidemiology of urothelial carcinoma. Int J Urol. 2017;24(10):730-4. doi: 10.1111/iju.13376.

2. Murta NC, Schmitz BJ, Zeegers MP, et al. Epidemiology of urinary bladder cancer: from tumor development to patient's death. World J Urol. 2007;25(3):285-95. doi: 10.1007/s00345-007-0168-5.

3. Emilio S, Luigi V, Riccardo B, et al. Lifestyle in urology. Cancer. Urologia. 2019;86(3):105-14. doi: 10.1177/0391560319846012.

4. Baris D, Karagas MR, Verrill C, et al. A case-control study of smoking and bladder cancer risk: Emergent patterns over time. J Natl Cancer Inst 2009;101:1553-61. doi: 10.1093/jnci/djp361.

5. Brennan $\mathrm{P}$, Bogillot $\mathrm{O}$, Cordier $\mathrm{S}$, et al.Cigarette smoking and bladder cancer in men: A pooled analysis of 11 case-control studies. Int J Cancer 2000;86:289-94.

6. Chen $\mathrm{CH}$, Shun $\mathrm{CT}$, Huang $\mathrm{KH}$, et al. Stopping smoking might reduce tumour recurrence in nonmuscle-invasive bladder cancer. BJU Int 2007;100:281-6 . doi: 10.1002/(sici)1097-0215(20000415)86:2<289::aidijc21>3.0.co;2-m.

7. Jiang X1, Yuan JM, Skipper PL, et al. Environmental tobacco smoke and bladder cancer risk in never smokers of Los Angeles County. Cancer Res 2007;67:7540-5 , doi: 10.1158/0008-5472.CAN-07-0048

8. May M, Fritsche HM, Gilfrich C, et al.What do patients with urothelial cancer know about the association of their tumor disease with smoking habits? Results of a German survey study. Investig Clin Urol. 2018;59(2):917. doi: 10.4111/icu.2018.59.2.91.

9. Babjuk M, Burger M, Compérat EM, et al.European Association of Urology Guidelines on Non-muscle-invasive Bladder Cancer (TaT1 and Carcinoma In Situ) - 2019 Update. Eur Urol. 2019;76(5):639-57. doi: 10.1016/j. eururo.2019.08.016.

10. Rouprêt M, Babjuk M, Compérat E, et al. European Association of Urology Guidelines on Upper Urinary Tract Urothelial Carcinoma: 2017 Update. Eur Urol. 2018;73(1):111-22. doi: 10.1016/j.eururo.2017.07.036

11. Hagiwara M, Kikuchi E, Tanaka N, et al. .Impact of smoking status on bladder tumor recurrence after radical nephroureterectomy for upper tract urothelial carcinoma. J Urol. 2013;189(6):2062-8. doi: 10.1016/j. juro.2013.01.024.

12. Wilcox AN, Silverman DT, Friesen MC, et al.Smoking status, usual adult occupation, and risk of recurrent urothelial bladder carcinoma: data from The Cancer Genome Atlas (TCGA) Project. Cancer Causes Control. 2016;27(12):1429-35. doi: 10.1007/s10552-016-0821-7. 
13. Sfakianos JP, Shariat SF, Favaretto RL, et al. Impact of smoking on outcomes after intravesical bacillus Calmette-Guérin therapy for urothelial carcinoma not invading muscle of the bladder. BJU Int. 2011;108(4):52630. doi: 10.1111/j.1464-410X.2010.09874.x.

14. 14.Ide $H$, Kikuchi $E$, Hagiwara $M$, et al. Urinary pH Levels are Strongly Associated with Bladder Recurrence After Nephroureterectomy in Upper Tract Urothelial Carcinoma Patients with a Smoking History. Ann Surg Oncol. 2016;23(5):1029-38. doi: 10.1245/s10434-016-5555-y.

15. Lee AS, Ozakinci G, Leung $S$, et al. Lifestyle change in the cancer setting using 'the teachable moment': protocol for a proof-of-concept pilot in a urology service. Pilot Feasibility Stud. 2016;21;2:65. doi: 10.1186/s40814016-0102-y. eCollection 2016

16. 16.May M, Gilfrich C, Spachmann P, et al. What do prostate cancer patients know about smoking? Results of a bicentric questionnaire study (KRAUT study)). Urologe A. 2016;55(8):1078-85. doi: 10.1007/s00120-016-0165-7.

17. 17. Hyndman K, Thomas RE, Schira HR, et al. Effectiveness of Tobacco Dependence Education in Health Professional Students' Practice: A Systematic Review and Meta-Analysis of Randomized Controlled Trials.Int J Environ Res Public Health. 2019;16(21):E4158. doi: 10.3390/ ijerph16214158.

18.18. Gray JL, Maghlouth AA, Hussain HA, et al. Impact of oral and oropharyngeal cancer diagnosis on smoking cessation patients and cohabiting smokers. Tob Induc Dis. 20191;17:75. doi: 10.18332/ tid/109413. eCollection 2019.

19. 19. Westhoff E, Neumayer J, Aben KK, et al. Low awareness of risk factors among bladder cancer survivors: New evidence and a literature overview. Eur J Cancer. 2016;60:136-45. doi: 10.1016/j.ejca.2016.03.071. Epub 2016 Apr 25. 